TITLE:

\title{
Dopamine induces a slow afterdepolarization in lateral amygdala neurons(Abstract_要旨)
}

\section{$\operatorname{AUTHOR}(S)$ :}

Yamamoto, Ryo

\section{CITATION:}

Yamamoto, Ryo. Dopamine induces a slow afterdepolarization in lateral amygdala neurons. 京都大学, 2008, 博士(医学)

ISSUE DATE:

2008-01-23

URL:

http://hdl.handle.net/2433/135791

RIGHT: 


\begin{tabular}{|c|c|}
\hline 氏 & $\begin{array}{l}\text { 山圭 占 } \\
\text { 山本 }\end{array}$ \\
\hline 学位 (専攻分野) & 博 士 (医 学) \\
\hline 学 位 記 番 号 & 医 博 第 3171 号 \\
\hline 学位授与の日付 & 平成 20 年 1 月 23 日 \\
\hline 学位授与の要件 & 学位規則第 4 条第 1 項該当 \\
\hline 研究科 · 専攻 & 医学研究科脳統御医科学系専攻 \\
\hline 学位論文題目 & $\begin{array}{l}\text { Dopamine induces a slow afterdepolarization in lateral amygdala } \\
\text { neurons } \\
\text { (ドーパミンは扁桃体ニューロンに拈いて遲いスパイク後脱分極を誘起する) }\end{array}$ \\
\hline
\end{tabular}

\section{論文内容 の 要旨}

扁桃体の神経活動と扁桃体に投射するドーパミン作動系の活動は協調して働き、情動行動の表出を適切に調節している事 が知られている。例えば扁桃体でドーパミンの作用を阻害すると、恐怖記憶形成などの情動反応が阻害される事が報告され ている。また in vitroの実験において、ドーパミンが扁桃体の興奮性伝達を増強する事や、扁桃体内の抑制性神経の活動を 抑制することが報告されている。しかし、ドーパミンが扁桃体神経そのものの特徴をどのように調節するかについては、ほ とんど知られていなかった。今回、ラットの脳スライスを用いて、外側扁桃体神経細胞からパッチクランプ記録を行い、ド 一パミンが外側扁桃体神経細胞の興奮性をどのように調節しているかを調べた。外液に $50 \mu \mathrm{M}$ のドーパミンを加えると、 $500 \mathrm{~ms} \cdot 200 \mathrm{pA}$ の通電に対して、一連の発火を示した後、神経細胞は 5 秒間程度持続する遅い後脱分極（dopamine-induced slow afterdepolarization: DA-induced sADP）を示した。このDA-induced sADP はドーパミン濃度依存的であった。次に ドーパミンがどのようにしてこの現象を惹き起こすかを、様々なモノアミン受容体アゴニスト・アンタゴニストを用いて調 べた。結果、D1 受容体のアゴニストSKF38393・SKF81297 はこの sADP を惹き起こしたが、その大きさはドーパミンに よるあのよりあ小さかった。D1 受容体のアンタゴニスト SKF83566 在下では、この sADP は小さくなった。D2 受容体の アゴニストQuinpirole、アンタゴニスト Sulpiride は共にこの S ADP に影響を与えなかった。さて、ここで、ノルアドレナ リン $\alpha 1$ 受容体のアンタゴニストPrazosin とセロトニン $2 \mathrm{~A}$ 受容体のアンタゴニスト Ketanserin の影響を調べると、双方 とも DA-induced sADP を抑制した。これらのことから、ドーパミン受容体だけでなく、ノルアドレナリン受容体・セロト ニン受容体にもドーパミンが作用して、この sADP をひきこしていると考えられる。次にこの sADPの発生機序について調 ベた。テトロドトキシンによるナトリウムチャネル阻害は、この SADP に影響を与えなかった。一方、カドミウムによるカ ルシウムチャネル阻害やBAPTAによる細胞内カルシウムキレートによって、この sADP は消失した。また、ボルテージク ランプ実験で、この sADP 電流が生じている間の細胞膜コンダクタンスの変化を調べたところ、電流が増大すると共に、膜 コンダクタンスは減少していた。この事は、なんらかのチャネルが閉じる事でDA-induced sADPが生じている事を示唆し ている。さらに細胞外カリウム濃度に応じて逆転電位が変化し、セシウム内液によるカリウムチャネル阻害で消失した事か ら、カリウム電流の減少によってこの sADP が生じる事が示唆された。これらの事から、この DA-induced sADP はカルシ ウム流入を契機とした、カリウム電流の減少によって生じると考えられる。この DA-induced sADP は入力を受けた神経細 胞の興奮性を活動依存的に上昇させ、情動行動時の扁桃体情報処理を正フィードバック的に調節していると考えられる。

\section{論 文 審 査 の 結 果 の 要 旨}

扁桃体へのドーパミン入力が情動の適切な発現に必要である事は知られているが、ドーパミンがどのように扁桃体神経興 奮性を調節しているかについては不明な部分が多い。申請者は、扁桃体でのドーパミンの役割を明らかにするために、ラッ ト脳スライスからパッチクランプ法を用いて、扁桃体神経興舊性をドーパミンがどのように調節するかを調べた。その結果、 
ドーパミンはドーパミン受容体のみではなく、ノルアドレナリン・セロトニン受容体む介してｓlow after-depolarization

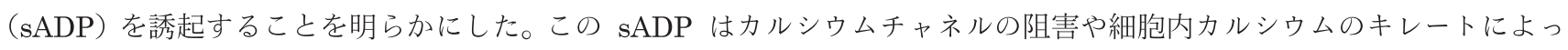
て消失した。また、SADP 電流が流れている間、膜コンダクタンスは減少しており、細胞外のカリウム濃度の変化に応じて 逆転電位が変化した。これらの事から、この sADP はカルシウム流入を契機とした、カリウム電流の減少によって生じる ことが明らかにされた。SADP は入力を受けた神経細胞の興奮性を活動依存的に上昇させ、情動行動時の扁桃体情報処理を ポジティブフィードバック的に調節していると考えられる。以上の研究は、扁桃体に扮いてドーパミンが $\mathrm{sADP}$ を惹き起 こし、モノアミン作動系と協調して扁桃体神経活動を調節していることを初めて示したあのであり、情動の適切な発現に関 わる扁桃体興奮性調節機序の解明に貢献するあのである。したがって本論文は博士（医学）の学位論文として価值あるもの と認める。

なお、本学位授与申請者は、平成 19 年 12 月 4 日実施の論文内容とそれに関連した試問を受け、合格と認められたあので ある。 